\title{
PHENOTYPIC EVOLUTION IN MICROALGAE: A DRAMATIC MORPHOLOGICAL SHIFT IN DICTYOSPHAERIUM CHLORELLOIDES (CHLOROPHYTA) AFTER EXPOSURE TO TNT
}

\author{
Victoria LÓPEZ-RODAS, Eduardo COSTAS, \\ Libertad GARCÍA-VILLADA \& Antonio FLORES-MOYA
}

\begin{abstract}
RESUMEN. Evolucion fenotipica en microalgas: un cambio morfológico espectacular en Dictyosphaerium chlorelloides (Chlorophyta) tras la exposición a TNT. Un cambio morfológico muy rápido tiene lugar en Dictyosphaerium chlorelloides (Chlorophyta) tras la exposición de cepas salvajes al potente alguicida 2,4,6 trinitrotolueno (TNT). Las cepas salvajes, sensibles al TNT, tienen una morfología típica esférico-elipsoidal. Tras exponer dichas cepas a dosis letales de TNT, solamente sobreviven células resistentes al tóxico cuya silueta es fusiforme. Estos resistentes fusiformes aparecen como consecuencia de mutaciones espontáneas que tienen lugar antes de exponer las cepas salvajes al agente selectivo (TNT): es decir, las células fusiformes estaban presentes en la población salvaje. La frecuencia de mutantes fusiformes en las poblaciones salvajes está definida por el equilibrio entre la tasa de acumulación de mutantes y la tasa en que son eliminados por tener una eficiencia biológica menor (10-10 $0^{2}$ mutantes fusiformes por $10^{6}$ células salvajes). Se propone que la selección de clones podría ser un mecanismo de evolución adaptativa en poblaciones de microalgas asexuales. Este evento opera mediante la selección de genotipos pre-selectivos que aparecen como consecuencia del incremento de la presión de selección como fruto de eventos catastróficos en el medio ambiente.
\end{abstract}

Palabras clave. Dictyosphaerium, evolución, microalgas, morfología, mutación, TNT.

\begin{abstract}
Phenotypic evolution in microalgae: a dramatic morphological shift in Dictyosphaerium chlorelloides (Chlorophyta) after exposure to TNT. The occurrence of rapid morphological evolution in the microalga Dictyosphaerium chlorelloides (Chlorophyta) was induced after exposure of the wild strains of the alga to the potent algal poison 2,4,6-trinitrotoluene (TNT). After exposing a wildtype population (consisted of representative spherical-ellipsoidal cells) to doses of TNT that were lethal for most of the cells, a TNT-resistant spindle-shaped mutant was able to proliferate. This spindleshaped mutant appeared spontaneously by rare mutations before the selective treatment: in deed, it was already present in the wild population. The frequency of the mutants within the ancestral population seemed to be determined by the balance between the rate of accumulation by recurrent mutation and the rate of elimination by selection (ranging 10-10 ${ }^{2}$ spindle-shaped mutants per $10^{6}$ cells). We hypothesize that clone selection could take place in asexual populations of microalgae by selection of rare, pre-selective genotypes, driven by a drastic selective pressure subsequent to a catastrophic environmental change.
\end{abstract}

Key words. Dictyosphaerium, evolution, microalgae, morphology, mutation, TNT. 


\section{INTRODUCTION}

The appearance of Dictyosphaerium chlorelloides (Naumann) Komárek and Perman (Chlorophyta) cells that are resistant to normally lethal doses of the potent algal poison 2,4,6-trinitrotoluene (TNT), after exposing a wild-type population to a selective concentration of this toxicant, was described by García-Villada et al. (2002). A fluctuation analysis (Luria \& Delbrück 1943) unequivocally demonstrated that the TNTresistant $\left(\mathrm{TNT}^{\mathrm{r}}\right)$ cells arose from spontaneous mutations occurring before the ancestral population was exposed to the toxic compound. In addition, the ancestral $\mathrm{TNT}^{\mathrm{s}}$ and the TNT $^{\mathrm{r}}$ cells seemed to be morphologically different. While the wildtype cells were spherical-ellipsoidal according to the species description, the mutants were spindle-shaped. Here, we experimentally analyzed this phenotypic evolution, which seems to be the result of a phenomenon of clone selection of rare mutants pre-existing in the ancestral population of $D$. chlorelloides after an extreme environmental change.

\section{MATERIAL AND METHODS}

A laboratory wild-type strain of $D$. chlorelloides (strain $\mathrm{TNT}^{\mathrm{s}}$ ) consisted of typical spherical-ellipsoidal cells of this species, from the algal culture collection of the Faculty of Veterinary, Complutense University. The initial inoculum was isolated in a high mountain lake in Sierra Nevada ( $S$ Spain). The morphological features of the strain $\mathrm{TNT}^{\mathrm{s}}$ were in agreement with those described in John \& Tsarenko (2002: 349) for the species. However, 2- or 4-celled colonies are very rare in cultures, being the species basically represented by singlecelled individuals. The strain was exposed to $30 \mathrm{mg} \mathrm{L}^{-1}$ of TNT as described in GarcíaVillada et al. (2002), in the experimental framework of a Luria \& Delbrück (1943) fluctuation analysis. This analysis allowed us to distinguish resistant cells that have their origin in random spontaneous preselective mutations (prior to TNT treatment) from those arising through acquired postselective adaptation (during the treatment with TNT). After TNT exposure, an unusual spindleshaped variant, which was resistant to the effect of TNT (strain TNT ${ }^{\mathrm{r}}$ ), was isolated and cultured. García-Villada et al. (2002) unequivocally demonstrated that the $\mathrm{TNT}^{\mathrm{r}}$ variant was a preselective mutant.

Ten independent clones from $\mathrm{TNT}^{\mathrm{s}}$ and $\mathrm{TNT}^{\mathrm{r}}$ strains were isolated from single vegetative cells and grown to mass populations. Because initial cells were randomly sampled, each established set of clones was expected to represent the morphological variation of its respective strain. Three replicates of every clone were established, each with $3 \times 10^{4}$ cells, and exponentially grown in culture tubes in $3 \mathrm{~mL}$ of BG-11 medium (Sigma Aldrich Chemie, Taufkirchen, Germany) at $20^{\circ} \mathrm{C}$ under continuous light $\left(200 \mu \mathrm{mol}\right.$ photons $\mathrm{m}^{-2} \mathrm{~s}^{-1}$ over the waveband 400-700 nm, provided by cool-white fluorescent tubes) for five days. These replicates were established with the aim of determining the within-clone morphological variation. Samples were then taken and 20 randomly-selected cells from each replicate were digitally photographed using a Zeiss Axiovert 35 (Oberkóchen, Germany) inverted microscope. In short, a total of 600 cells from each strain (10 clones $\times 20$ cells per clone $\times 3$ replicates) were photographed. For each cell, the area (A) and perimeter $(\mathrm{P})$ were directly measured using an image analysis system (Motic Digital Imaging 3.5, Motic, Xiamen, PCR). As a measure of the shape of the cells, the coefficient of form (CF) proposed by Renau- 
Piqueras et al. (1985) was calculated:

$$
\mathrm{CF}=(4 \pi \mathrm{A}) / \mathrm{P}^{2}
$$

According to the formulae of surface area of a circle, and the length of its circumference, a $\mathrm{CF}=1$ is derived; identically, the surface area and the perimeter of an ellipse with semi-axes of 1 and 0.5 , respectively, yields a $\mathrm{CF}=0.8$.

The CF from both $D$. chlorelloides strains were compared by a nested ANOVA using the model:

$$
y=\text { Strain }+ \text { Clone }[\text { Strain }]+\text { Error }
$$

As long as replicates were the experimental units, the mean $\mathrm{CF}$ value for every replicate was calculated prior to data analysis, being then introduced in the analysis as replicate value. Homocedasticity was checked by the $F_{\max }$-test. Statistical analyses were accomplished in accordance with Sokal \& Rohlf (1995).

In addition, within the ancestral $\mathrm{TNT}^{\mathrm{s}}$ strain with the typical spherical-ellipsoidal shape of the species, we made a detailed microscopy search for the presence of any variants with an unusual spindle shape.

\section{RESULTS}

Morphological differences between wild-type population of $D$. chlorelloides and the variant that was resistant to the effect of TNT were noticeable under light microscope (fig. 1). The wild-type cells showed the typical spherical-ellipsoidal shape of this species, whereas the $\mathrm{TNT}^{\mathrm{r}}$ variant showed an unusual spindle shape. In accordance with this observation, the average $\mathrm{CF}$ value for the wild-type cells was $>0.9$ (fig. 2), as is to be expected in circular outlines. In contrast, the $\mathrm{TNT}^{\mathrm{r}}$ cells showed a $\mathrm{CF} \approx 0.8$ (fig. 2),

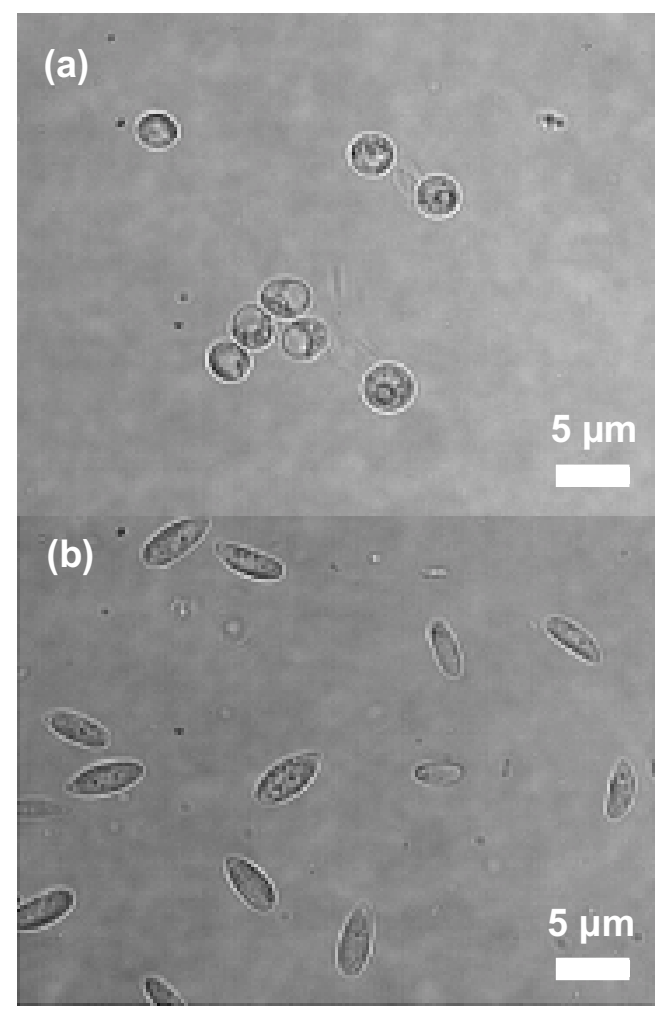

Figure. 1. Dictyosphaerium chlorelloides cell morphology. (a) Wild-type, TNT-sensitive cells, showing the typical spherical-ellipsoidal shape of the species. (b) Spindle-shaped, TNT-resistant variant. Morfología celular de Dictyosphaerium chlorelloides. (a) Cepa salvaje, sensible al TNT, con típica morfología esférica-elipsoidal. (b) Cepa resistente al TNT con silueta fusiforme.

which is an expected value for spindleshaped outlines with semi-axes in a ratio 1:2. The differences in CF between strains were statistically significant; moreover, no such differences were detected among clones within each strain (tab. 1).

After searching for variants with unusual ellipsoidal shape within the ancestral wild-type population of $D$. chlorelloides, it was found the first spindle-shaped cell after examining 9,116 cells, and the second one after checking a total of 39,438 cells. That 


$\begin{array}{lcccc}\text { Source of variation } & \text { df } & \text { SS } & F & P \\ \text { Strain } & 1 & 0.302 & 384.43 & <0.0001 \\ \text { Clone [Strain] } & 18 & 0.014 & 1.09 & 0.40 \\ \text { Error } & 40 & 0.029 & & \end{array}$

Table 1. Two-way, mixed nested model ANova for coefficient of form in Dicyosphaerium chlorelloides $(n=60)$. ANOVA jerarquizado de 2 vías para el coeficiente de forma en Dicyosphaerium chlorelloides $(n=60)$.

is to say, a frequency of 51 and 110 spindleshaped cells per $10^{6}$ cells was computed. This estimation of the frequency of the presence of TNT $^{\mathrm{r}}$ spindle-shaped cells in the wild-type population must be considered as an approximation, due to the low number of counts, and the time-consuming and cumbersome aspects of the visual analysis. Nevertheless, a frequency of $10-10^{2}$ spindleshaped cells per $10^{6}$ cells in the ancestral population could be considered as a reasonable estimation.

\section{DISCUSSION}

The key to understanding the dramatic change in $D$. chlorelloides cell morphology is to analyze the origin of the variant with the unusual spindle shape, which proliferated after the massive destruction of the typical spherical-ellipsoidal cells subsequent to the extreme environmental change, i.e., TNT exposure. The general problem of whether microorganisms adapt to novel environments through individual 'active' responses, or through selection of rare spontaneous mutations, has engendered an interesting debate (Sniegowski \& Lenski 1995; Sniegowski et al. 2000). As it was previously demonstrated in other algal species (Costas et al. 2001; López-Rodas et al. 2001; Baos et al. 2002; García-Villada et al. 2002, 2004; Flores-Moya et al. 2005), the selective factor does not facilitate the occurrence of resistant mutants; rather it was found that these latter appear spontaneously by rare mutations prior to the selective treatment. Consequently, the resistant spindle-shaped variant already would be living in the $D$. chlorelloides population prior to the extreme environmental change.

In the absence of the selective factor, the spindle-shaped resistant mutants would exhibit diminished fitness, photosynthetic capacity and efficiency (García-Villada et al. 2002) and quantum yield (Altamirano et al. 2004) which impairs their survival within $D$. chlorelloides populations. However, mutations are recurrent, and in each generation new resistant mutants might arise. Although most of these mutants disappear sooner or later due to natural selection, at any given time there will be a certain number of mutant cells that have not yet been eliminated. The frequency of such mutants (q) will be determined by the balance between the accumulation rate by mutation and the rate of elimination by selection:

$$
q=\mu /(\mu+s) \approx \mu / s
$$

where $\mu$ is the mutation rate, and $s$ is the selection coefficient of the mutant (Kimura \& Maruyama, 1966), calculated as follows:

$$
s=1-\left(m_{\mathrm{TNT}}^{\mathrm{r}} / m_{\mathrm{TNT}}^{\mathrm{s}}\right)
$$

where $m_{\mathrm{TNT}}^{\mathrm{r}}$ and $m_{\mathrm{TNT}}$ s are the Malthusian parameters of fitness from the $\mathrm{TNT}^{\mathrm{r}}$ and $\mathrm{TNT}^{\mathrm{s}}$ 


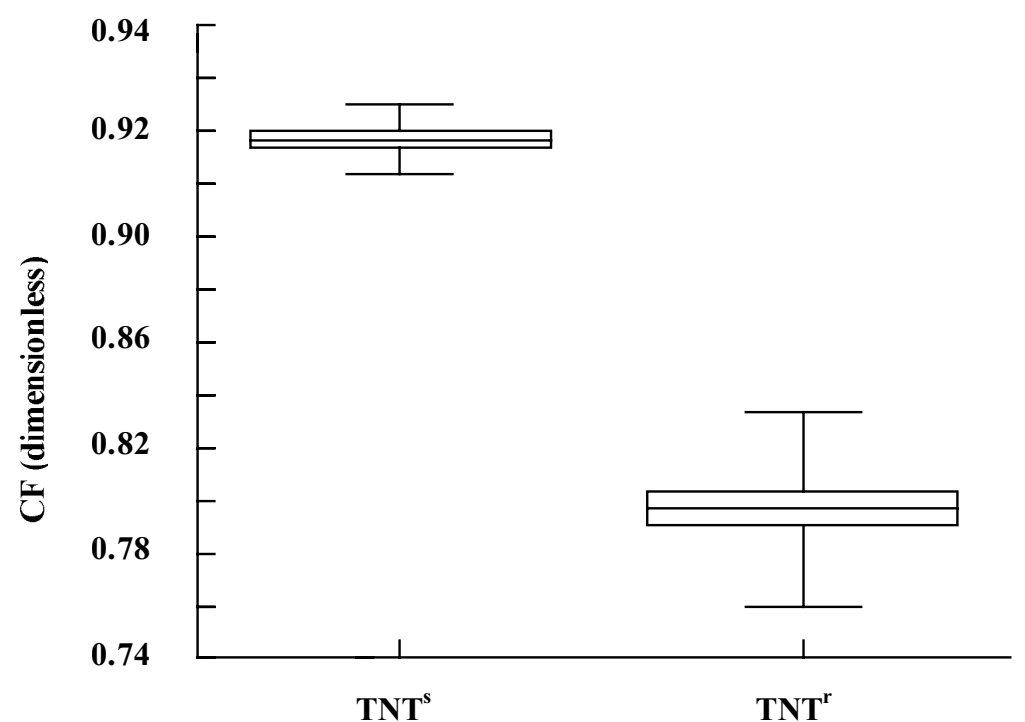

Figure 2. Box-Whiskers representing mean, SE and SD for coefficient of form (CF) in the wild-type $\left(\mathrm{TNT}^{\mathrm{s}}\right.$ ) and mutant $\left(\mathrm{TNT}^{\mathrm{r}}\right)$ Dictyosphaerium chlorelloides strains. A total of 600 cells from each strain were measured $(10$ clones $\times 20$ cells per clone $\times 3$ replicates). Representación de tipo "Box-whiskers" para la media, SE y SD del coeficiente de forma (CF) de las cepas salvajes (TNT ${ }^{s}$ ) y mutante (TNT $\left.{ }^{r}\right)$ de Dictyosphaerium chlorelloides. Se midieron 600 células de cada una de las cepas (10 clones $\times 20$ células por clon $\times 3$ réplicas).

strains, respectively. Using the values of $\mu$ $\left(1.4 \times 10^{-5}\right.$ mutants per cell division; see fig. 1 in García-Villada et al. 2002) and the relative values of $m_{\mathrm{TNT}}{ }^{\mathrm{r}}$ and $m_{\mathrm{TNT}}$ s $(0.6$ and 1 , respectively; see fig. 2 in García-Villada et al. 2002), of each $10^{6}$ cells in the ancestral population of $D$. chlorelloides, $\approx 35$ resistant mutants of spindle-shaped cells could be expected. The results from our cell-shape survey were in agreement with this estimation because we found that the frequency of spindle-shaped cells fell in a range of $10-10^{2}$ per $10^{6}$ cells in the ancestral, wild-type population of $D$. chlorelloides. Thus, the ancestral D. chlorelloides population growing in an uncontaminated environment was constituted, predominantly, by a clonal line of wild-type genotype (spherical-ellipsoidal phenotype) and, simultaneously in a very small fraction, by a clonal line of $\mathrm{TNT}^{\mathrm{r}}$ mutants (spindle phenotype). After the extreme environmental change due to contamination by TNT, the spindle-shaped marginal clone line was able to grow, whereas the spherical-ellipsoidal wild-type clone became extinct.

Lenski \& Travisano (1994) and Elena et al. (1996) showed that the cell size of an experimental Escherichia coli population evolved rapidly due to successive beneficial mutations rapidly spreading in the microbial population by natural selection. Here, we hypothesize that even more rapid could take place in asexual populations of microalgae by clone selection of rare extreme preselective genotypes, driven by a drastic selective pressure subsequent to a catastrophic environmental change.

The dramatic morphological shift found in D. chlorelloides after exposure to TNT is a singular fact because we did not found any similar morphological shift after exposure of 
several cyanobacteria and microalgal species to lethal doses of biocides such as the herbicide 3-(3', 4'-dichlorophenyl)-1,1dimethylurea (Costas et al. 2001), antibiotics (López-Rodas et al. 2001), copper sulphate (García-Villada et al. 2004) or a cocktail of heavy metals (Baos et al. 2002). However, in freshwater systems located in urban or agricultural areas, microalgae are exposed to a multitude of toxicologically different pesticides (Junghans et al. 2006) and, therefore, it could be hypothesized that the appearance of resistant mutants can simultaneously determine the arising of new morphological populations driven by algaecide-resistant clones. However, this aspect remains to be investigated by using more biocides and algal species.

From a taxonomical point of view, the spindle-shaped TNT $^{\mathrm{r}}$ strain must be considered as $D$. chlorelloides, but in an extreme of its morphological variation, because cell morphology of this species range from spherical to asymmetrically obovoid cells (John \& Tsarenko 2002). Thus, it can be supposed that the mechanism linked to resistance to TNT is also implied in the arrangement of microtubules in the cells, or in the expression and control of cytoskeleton regulators.

Modern synthetic chemicals often are the cause of water pollution in inland water systems worldwide, and could exert drastic selective pressures that allow rapid fixation of rare pre-selective mutants in natural populations of microalgae after only one exposure. The case of TNT is an interesting example.

ACKNOWLEDGMENTS. This work was financially supported by REN 2000-0771 HID, REN 2001-1211 HID, Parques Nacionales 093/ 2003 and P05-RNM-00935 grants. Eric C. Henry (Herbarium, Department of Botany and Plant Pathology, Oregon State University, USA) kindly revised the English style and usage. We thank M. J. Puertas (Genetics, Faculty of Biological Sciences, Complutense University, Madrid) for discussion and comments.

\section{REFERENCES}

ALTAMIRANO, M., L. GARCÍA-VILLADA, M. AGRELO, L. SÁNCHEZ-MARTÍN, L. MARTÍN-OTERO, A. FLORES-MOYA, M. RICO, V. LÓPEZ-RODAS \& E. COSTAS 2004- A novel approach to improve specificity of algal biosensors using wild-type and resistant mutants: an application to detect TNT. Biosens. Bioelectron. 19: 1319-1323.

BAOS, R., L. GARCÍA-VILLADA, M. AGRELO, V. LÓPEZ-RODAS, F. HIRALDO \& E. COSTAS -2002- Short-term adaptation of microalgae in highly stressful environments: an experimental model analysing the resistance of Scenedesmus intermedius (Chlorophyceae) to the heavy metals mixture from the Aznalcóllar mine spill. Eur. J. Phycol. 37: 593-600.

COSTAS, E., E. CARRILLO, L. M. FERRERO, M. AGRELO, L. GARCÍA-VILLADA, J. JUSTE \& V. LÓPEZ-RODAS -2001Mutation of algae from sensitivity to resistance against environmental selective agents: the ecological genetics of Dictyosphaerium chlorelloides (Chlorophyceae) under lethal doses of 3-(3,4dichlorophenyl)-1,1-dimethylurea herbicide. Phycologia 40: 391-398.

ELENA, S. F., V. S. COOPER \& R. E. LENSKI R.E.-1996- Punctuated evolution caused by selection of rare beneficial mutations. Science 272: 1802-1804.

FLORES-MOYA, A., E. COSTAS, E. BAÑARES-ESPAÑA, L. GARCÍAVILLADA, M. ALTAMIRANO \& V. LÓPEZRODAS -2005-Adaptation of Spirogyra insignis (Chlorophyta) to an extreme natural environment (sulphureous waters) through preselective mutations. New Phytol. 165: 655661.

GARCÍA-VILLADA, L., V. LÓPEZ-RODAS, E. BAÑARES-ESPAÑA, A. FLORES-MOYA, M. AGRELO, L. MARTÍN-OTERO \& E. 
COSTAS -2002- Evolution of microalgae in highly stress environments: an experimental model analyzing the rapid adaptation of Dictyosphaerium chlorelloides (Chlorophyceae) from sensitivity to resistance against 2,4,6-trinitrotoluene by rare preselective mutations. J. Phycol. 38: 10741081.

GARCÍA-VILLADA, L., M. RICO, M. ALTAMIRANO, L. SÁNCHEZ-MARTÍN, V. LÓPEZ-RODAS \& E. COSTAS -2004Occurrence of copper resistant mutants in the toxic cyanobacterium Microcystis aeruginosa: characterization and future implications in the use of copper sulphate as an algaecide. Water Res. 38: 2207-2213.

JOHN, D. M. \& P. M. TSARENKO -2002- Order Chlorococcales. In D. M. JOHN, B. A. WHITTON \& A. J. BROOK (eds.), The Freshwater Algal Flora of the British Isles. An Identification Guide to Freshwater and Terrestrial Algae. Cambridge University Press, Cambridge, UK.

JUNGHANS, M., T. BACKHAUS, M. FAUST, M. SCHOLZE \& L. H. GRIMME -2006Application and validation of approaches for the predictive hazard assessment of realistic pesticide mixtures. Aquat. Toxicol. 76: 93110.

KIMURA, M. \& T. MARUYAMA -1966- The mutational load with epistatic gene interactions in fitness. Genetics 54: 13371351 .

LENSKI, R. E. \& M. TRAVISANO -1994Dynamics of adaptation and diversification: a 10,000-generation experiment with bacterial populations. Proc. Nat. Acad. Sci. USA 91: 6808-6814.

LÓPEZ-RODAS, V., M. AGRELO, E. CARRILLO, L. M. FERRERO, A. LARRAURI, L. MARTÍN-OTERO \& E. COSTAS -2001- Resistance of microalgae to modern water contaminants as the result of rare spontaneous mutations. Eur. J. Phycol. 36: 179-190.

LURIA, S. E. \& M. DELBRÜCK -1943Mutations of bacteria from virus sensitivity to virus resistance. Genetics 28: 491-511.

RENAU-PIQUERAS, J., C. GÓMEZ-PERRETA, C. GUERRI \& R. SANCHIS -1985-
Qualitative and quantitative ultrastructural alterations in hepatocytes of rats prenatally exposed to ethanol with special reference to mitochondria, golgi apparatus and peroxisomes. Virchows Arch. 405: 273-251.

SNIEGOWSKI, P. D. \& R. E. LENSKI -1995Mutation and adaptation: The directed mutation controversy in evolutionary perspective. Annu. Rev. Ecol. Syst. 26: 553578.

SNIEGOWSKI, P. D., P. J. GERRISH, T. JOHNSON \& A. SHAVER -2000- The evolution of mutation rates: Separating causes from consequences. BioEssays 22: 10571066.

SOKAL, R. R. \& F. J. ROHLF -1995- Biometry, $3^{\text {th }}$ ed. W.H. Freeman and Company, New York, NY, USA.

Aceptado para su publicación en septiembre de 2006

Dirección de los autores. V. LÓPEZ-RODAS, E. COSTAS y L. GARCÍA-VILLADA: Producción Animal (Genética), Facultad de Veterinaria, Universidad Complutense, Avda. Puerta de Hierro s/n, 28040 Madrid, España; A. FLORES-MOYA: Biología Vegetal (Botánica), Facultad de Ciencias, Universidad de Málaga, Campus de Teatinos s/n, 29071 Málaga, España (email: floresa@uma.es). 